УДК 9

DOI $10.21661 / \mathrm{r}-115589$

\title{
К.М. Некзад
}

\section{ВЗАИМООТНОШЕНИЯ БУХАРЫ И ИРАНА В ХVII-ХVIII ВВ.}

Аннотация: в статье рассмотрены взаимоотношения Бухары и Ирана в XVII-XVIII вв., которые по причине кровопролитной борьбы этих стран за расширение своих территорий были враждебными и сложными. Сефевиды прежде всего хотели овладеть Балхом, так как он служил важным стратегическим плачдармом для вторжения во внутренние районы Мавераннахра. В борьбе против Сефевидов активное участие принимали и балхские правители.

Ключевые слова: Балх, взаимоотночение, Сефевиды, Бухара, Хорасан, отряд, войско, набеги, Иран, правитель, посол, осада.

\section{K.M. Nekzad}

\section{BUKHARA-IRAN RELATIONS IN XVII-XVIII CENTURIES}

Abstract: the article describes Bukhara-Iran relations in XVII-XVIII centuries, which were hostile and difficult due to the bloody battles of these countries for their territorial expansion. Safavids primarily wanted to seize Balkh, as it was an important strategic base for the invasion in Maverannahr hinterland. Balkh leaders took an active part in the fight against Safavids.

Keywords: Balkh, relationship, Safavids, Bukhara, Khorasan, detachment, army raids, Iran, the governor, ambassador, siege.

According to written sources, the relationship of Bukhara and Iran in XVIIXVIII centuries were hostile and difficult because of the struggle of these countries for the enlargement of their territories. In these battles Balkh rulers have also been actively involved.

Safavids from the Sheibanids reign fought for mastery of Balkh, but were defeated. When the power in Balkh passed into the hands of Dzhanid Valimuhammad Khan, they 
did not want to put up with this and again led an intense preparation for a new invasion to assign their protege. Ashtarkhanids wanted to prevent war and to normalize relations between the two countries. To this end, they entered into negotiations with the Shah Abbas through the ruler of Merv - Bektas Khan, and sent Baýramaly Shamlu [1, p. 612-613] to Bukhara. But preventing the impending war was not successful.

Shah Abbas gathered forty thousand army and moved to Khorasan in the early 1602. He spent two months in pastures of Bagdysa replenishing army with new powers, fodder and provisions. After preparation, the Shah moved to Meruchak and soon reached Chechekta [1, p. 629]. Wali Muhammad sent to the Maurya to his brother Baqi Muhammad Khan a messenger with news about it. Baqi Muhammad Khan in August 1602 reached the banks of the Amu Darya and, after crossing the river, left heavy guard at the crossings, and went to Balkh. Ultimately, in the decisive battle in Pul-Hatab Safavids were defeated and Shah Abbas fled to Iran [3, 1. 66b, 67a-68b]. Thus, the Safavid rulers of Iran's attempt to put on the throne of Balkh their protégé ended in failure.

In 1605, Shah Abbas embarked again to put Jehangir Khan on the throne of Balkh. In the same year, Jehangir Khan seized Garchistan and part of Hazaredzhat and settled in Ubeh and Shafelan [1, p. 961;2, 1. 82a, 173b]. At the end 1606, he gathered an army from the highlanders of Hazaredzhat and accompanied by a detachment of the Safavid, again invaded the Balkh. Shahbek kukeltash, the governor of Balkh, and local rulers Maimana, Sheberghan, Gurzuvan and other places have strengthened their fortress and informed Wali Muhammad Khan of the dangers, who, after the death of his brother Buki Muhammad Khan became the ruler of Bukhara. Wali Muhammad Khan sent to their aid a large army under the command of Hadji-bey. At this time, Jehangir Khan and Salim Sultan approached Murghab and crossed it, and Katagans militia joined them in Meruchak. There was a bloody battle in Almar district; both armies suffered heavy losses. In the end, victory went to Dzhanids, and survivors Jehangir Khan and Salim Sultan fled to Garchistan, but were unable to gain a foothold there, and were knocked out by following Ashtarhanids army $[2,1.174 \mathrm{a}]$. According to Mahmud ibn Wali, in the middle of 1606 they reappeared within Chekekta and Gurzuvan. Nadir Muhammad Khan, the newly appointed governor of Balkh, sent troops against them, but they could not find them there [2, 1. 175a]. In 1607, 
Jehangir Khan and Salim Sultan again invaded Balkh through Dzhuzdzhan, however, the Safavids' attempt to put their protégé in Balkh ended unsuccessfully.

Safavids have made new attempts to conquer Balkh. They decided to push the Khan of Bukhara with the governor of Balkh, and thus weaken them, and then put Balkh under the control. To implement such a plan an opportunity has emerged. As is known, in 1610 the relationship between Wali Muhammad Khan and his nephews: Imam-Kuli-Sultan and Muhammad Nadir Khan, who ruled in Samarkand and Balkh, finally deteriorated because of the desire of the latter to independence. Shah Abbas, using a convenient opportunity, decided to support the Khan of Bukhara. For this purpose, 1610 afavid Ambassador Mirza Ali-Bey arrived in Bukhara and Bukhara Ambassador Mirza Shahmuhammad was sent to Isfahan. The subject of the negotiations was the relationship between the two countries. In honor of the Ambassador of Bukhara magnificent receptions were arranged in Isfahan.

At the beginning of 1611, Imam-Quli Khan and Nadir Muhammad began military operations, and reached Garm, and camped at Tang-Haram town. Wali Muhammad Khan of Bukhara raised against them, and, before reaching the area of Katlish located between Karshi and Khoja Obi Garm, he learned about the betrayal of a number of Samarkand beks. However, many of his supporters and soldiers, leaved him and joined forces of sultans. The Khan was very upset and returned to Bukhara. There sultans rose against him and those soldiers who left him joined those sultans. All the efforts of Wali Muhammad Khan to protect Bukhara was unsuccessful.

At the end of 1620 Rustam Khan, son of Wali Muhammad Khan with the support of two thousand detachment with the support of kyzylbashskih forces headed to Meruchak. Nadir Muhammad Khan sent against them a part of his army, as a result of a fierce battle Safavids were defeated and fled back in the direction of Herat [2, 1. 192a-194b].

Activation of Rustam-Sultan and Safavids on the borders of Balkh forced Nadir Muhammad Khan to keep large forces in the border districts. In addition, because of the constant attacks of the Kazakh sultans within Maverannahr he had to send back a large part of the army to help his older brother [2, 1. 111b; 1, 963-964]. Naturally, Nadir Muhammad Khan could not fight simultaneously on two fronts, and therefore entered into negotiations with the Shah Abbas 1 for the normalization of relations between the two countries. To 
this end, in 1621, the Balkh Ambassador Payanda Mirza arrived in Isfahan with rich gifts. Balkh Shah and Ambassador agreed on the strengthening of peace and friendship between the two countries. With rich gifts and a message of peace and harmony then the Iranian Ambassador Muhammad Salih Bey, the former vizier of Shirvan [1, p. 963, 983] came to Balkh. He came in Balkh with rich gifts and a message of peace and harmony as the Iranian ambassador. However, the «peace» step of the Shah proved to be diplomatic stunt aimed at insulation of the Balkh government on the eve of a large hike in the Safavid to Kandahar to which he was preparing intensively. In 1622 Iran sent another embassy from Balkh, headed by Syed Ibrahim Khoja. Witness of this event Iskander Munshi, said that Balkh Ambassador assured the Shah that the Imam-Quli Khan and Nadir Muhammad Khan desires only peace and friendship with him, and cause of the tension between their countries is Rustam - Sultan, who resides near Balkh borders and often devastates border districts. The Ambassador also made it a condition that the normalization of relations, the Sultan should take Rustam Shah back [1, p. 692]. However, the promise was not fulfilled and Rustam - Sultan still continued devastating raids on the possession of Balkh.

Nadir Muhammad Khan decided to permanently end this hotbed of unrest and in the autumn of 1623 directed to the side of Bala Murghab a large army under the command of Yalangtush-bey, and sent his envoy Payanda Chukhrov Mirza Aghasi-rich to Iran gifts and his expression of feelings of friendship. Balkh ambassador had lengthy negotiations with the Shah and as per the agreement reached with Nadir Muhammad Khan Bala Murghab district was given way to Iran [7, 1. 199b; 1, 994].

Following these events, Imamkuli Khan sent to the Shah his ambassador Abdulrahim-Haja, who expressed his «feelings of friendship and reassurance on the strengthening of peace and friendship between the two countries» [1, p. 978, 983].

Shah Abbas I wrote a reply to Muhammad Nadir Khan, gave it into the hands of the former Minister of Shervan - Muhammad Salih Bey and «together with visiting Payanda Mirza and Abdarrahim-Haji send saw them off» [1, p. 983].

Peaceful relations between Dzhanids and Safavids were violated since 1631, during the reign of Shah Safi 1 (1629-1642). 
In 1631 Rustam Sultan reappeared in Ubehe and invaded the south-western districts of Balkh region. Especially severe robberies related to surrounding areas of Meruchak, Maimana and Dzhuzdzhan. In the spring of 1632, jointly with Zein al-Khan and Huseynkuli Khan, the governors of Herat and Mashhad, he repeated this foray, and then, fearing his pursuers (Yalangtush atalyk, Baki-biya Divanbegi et al.), took refuge in a strong border fortress of Meruchak. Abd al-Aziz Sultan laid siege to the fortress, but was unable to master it. Abd al-Aziz-Sultan and Yalangtush-biy, making peace with the deposited on the condition that Rustam-Sultan and his allies return the loot and will be promptly sent to Balkh kharaj, lifted the siege and returned to Sheberghan [2, 1. 206b-209b].

In 1632-1637 Abd al-Aziz-Sultan repeatedly raided Khorasan, plundered the districts of Herat and Mashhad neighborhood and even once (in 1637) subjected Herat to the siege. Safavids continued support of Rustam-Sultan, who had settled this time (from 1630) in Mashhad [2, 1. 222b-236a]. However, these mutual devastating attacks have not prevented Bukhara Khan and Shah of Iran to maintain diplomatic relations, in which the parties did not forget their own interests.

In 1689 Subkhankuli Khan (1680-1702) made a trip to Khorasan. Bukhara residents captured the fortress of Balae Murghab (to the north-east of modern Kushka) surrendered to the Safavids by Nadir Muhammad Khan for friendly relations [6, p. 126-133]. Bukhara, Balkh and Badakhshan troops entered there through Andhud, besieged him with a dense ring. A few days later Abdallah Sultan, the ruler of the Safavid region, was forced to surrender the fortress to dzhanids emirs.

Property of the inhabitants of the fortress and the surrounding area was looted, wives and children were captured [5, 1. 138b].

After the death of Ubeydallah Khan in 1711, when the throne was given to his brother Abul Faiz Khan (1711-1747), Balkh again came under the influence of the Safavid. The Balkh throne was given to a descendant of Dzhanid, Wali Muhammad Khan Abdullah a protégé of the Safavids. Board appointees of Safavid Iran in Balkh continued until the invasion of Balkh troops of Nadir Shah (1737).

In March 1736 to the throne of Safavid Nadir Shah Afshar (1736-1747) raised who instructed his eldest son Rizakuli Mirza and emir Tahmasp Khan dzhalair to conquer 
Balkh. Campaign of Rizakuli Khan to Balkh began in spring of 1737. They surrounded the fortress. The defenders of the fortress steadfastly resisted for forty days, but the famine forced to surrender andhuds [5, 1. 99a-100b]. Safavids destroyed Andhuda fortress and subjected the whole area to ruin $[3,1.17 \mathrm{a}]$.

Rizakuli Khan appointing to Andhud Niyazkuli Dadkhah and sending to Chekekty and Sheberghan part of his army, went to Balkh. Ultimately, in 1737 Balkh and its district (Andhud, Sheberghan, Chechekty, Sanuchenharyak et al.) moved into the hands of Rizakuli Khan [4, 1. 107a].

It should be noted that subordinating Balkh, Safavids seized the initiative in the fight against Dzhanids and subsequently Balkh served as an important strategic base for the invasion into the hinterlands of Maverannahr.

Endless wara, which were led by Nadir Shah in 1739 against the Bukhara Khanate, significantly depleted material and human resources of Balkh and its districts. The population was forced to deliver to his vast army, not only provisions, fodder, the funds, but also support the construction units and militias. So, before the opening of hostilities against Bukhara, Nadir Shah ordered the governor of Balkh, Niyaz Khan to construct pontoon bridges across the Amu Darya from Termez and crossings Kelif and collect troops from subservient Balkh districts.

In the spring of 1741, Nadir Shah with a large army reappeared in Balkh due to the rebellion of the Kongurat tribe, and residents of the city and its districts for ten days were forced to feed them and collect for its army 7,500 soldiers [5, л. 154a, 256a]. According to Muhammad Kazim, Nadir Shah distrusted Niyaz Khan and, in January 1741, he sent to Balkh as the vizier his trusted official Mirza Beg Ma'dani Nishapuri [5, p. 283b]. The masses of Balkh, Andhud and other districts of the country responded with mass demonstrations in 1742 and 1745 against cruelty and lawlessness perpetrated by Safavi troops.

Thus, the inter-state relations of the Safavids with Dzhanids, passing the test of fire and blood, eventually resulted in kind relations of friendship and peace.

\section{References}

1. Iskandar Beg Turkman. Ta'rihi 'alam-Araya Abbasi. - Volume II, Tehran, 1387. 
2. Mahmud ibn Wali. Bahr al-Asrar al-fi Manaqib ahyar. A photocopy of the manuscript library of the India Den, Inv. - Number 575.

3. Muhammad Wafa Karminagi. Tuhfai Hani. Hands. VI in English. - Number 2604.

4. Muhammad Qasim Marvi. 'Alam-Araya Nadiri. - Volume II, Tehran, 1364.

5. Muhith at-Tawarikh, RCP. AS RU IV. - Number 835.

6. Hodge Samandar Termezi. «Dastur al-Muluk» («Edification sovereigns»). The facsimile of the oldest manuscript, translated from Persian, foreword, notes and pointers MA Salahetdinovoy. - Moscow, 1971.

7. Hodzhamkuli Bey Balkhi. Ta'rihi Kipchak-Hani. A photocopy of the manuscript Bodleian Libraries number 117.

Некзад Келорази Мир Нуроддин - соискатель Института истории, археологии и этнографии им. А. Дониша Академии наук Республики Таджикистан, Республика Таджикистан, Душанбе.

Nekzad Kelorazi Mir Nuroddin - aspirant of A. Donisha Institute of History, Archeology and Ethnography of Republic of Tajikistan Academy of Sciences, Republic of Tajikistan, Dushanbe. 